DOI 10.31558/2519-2949.2021.3.10

УДК 321.02:323.21:323.22:327.7

ORCID ID: https://orcid.org/0000-0003-3922-7619

Чальцева О. М., Донецький національний університет імені Василя Стуса

ORCID ID: https://orcid.org/0000-0001-5272-3268

Швець К. А., Донецький національний університет імені Василя Стуса

\title{
ДОСВІД ВПРОВАДЖЕННЯ ПУБЛІЧНИХ Е-КОНСУЛЬТАЦІЙ У ЄВРОПЕЙСЬКИХ КРАЇНАХ
}

У статті досліджено досвід впровадження публічних е-консультаиій у європейських краӥнах, зокрема у Великобританії, Нідерландах, Хорватії, Сербії та Україні.

Виявлено, щео публічні консультаиії, зокрема й у електронному форматі дозволяють посилити рівень довіри громадян до владних інститутів, налагодити ефективний діалог між владою та громадськістю, підвищити ступінь прозорості, прогнозованості, обтрунтованості та якості рімень, які ухвалюються органами державної влади та місиевого самоврядування, розширити доступ громадян до інформачії про діяльність цих органів, забезпечити більш ефективне використання публічних фінансів, усунути ряд корупційних ризиків при прийнятті нормативноправових актів.

Завдяки впровадженню у державну політику публічних опline консультацій у досліджуваних європейських краӥнах встановлено, що публічне консультування має структурний та системний підхід, а публічний характер онлайн консультацій сприяє прозорості процесу прийняття політичних рішень; забезпечується модернізаџія процесу державного управління відповідно до нових умов інституиіонального розвитку; підвищується ефективність і дієвість інститутів влади та держави, а також створюється можливість стійкого зворотного зв 'язку між владою, бізнесом і громадянами.

Виявлено, щзо Украӥна активно включилася в інтерактивний процес, що можна віднести до позитивних ефектів інституціоналізації публічної політики. Однак, варто зазначити, щзо в Україні публічні консультації з громадськістю практично жодним чином не врегульовані на рівні законодавства. При иьому місиеві ради самостійно визначають порядок і конкретні формати проведення консультацій шляхом їх закріплення у статуті та інших нормативно-правових актах. Впровадження електронних технологій у сфери публічного управління і розширення інформаційного простору дозволяс державним органам не лише надавати більш якісні послуги, а й провести децентралізацію, одночасно зміџнюючи горизонтальні зв 'язки між ланками системи управління, посилюючи зворотній зв'язок між представниками органів влади та громадянами. Публічні консультації в сучасному політичному просторі України мають на меті забезпечувати постійне коригування діяльності органів влади з урахуванням побажань $i$ запитів населення.

Ключові слова: публічна політика, публічне управління, публічне консультування, органи державної влади, громадянське суспільство, публічні е-консультації.

Публічна політика в глобальному масштабі вимагає максимальної співучасті акторів у формуванні нового управлінського, комунікативного та ідеологічного концепту світового розвитку. В умовах посиленої інформатизації, розвитку нових технологій, триваючої глобалізації світової економіки, розмивання національно-державних кордонів, збільшення конфліктності, появи нових проблем в області екології, охорони здоров'я та ін., об'єктивно відбувається розширення i ускладнення порядку денного, трансформація міжнародних і державних політичних інститутів, зміна ролей і функцій більшості гравців на національному, регіональному та світовому рівні. У той же час з'явилося безліч нових акторів політики, здатних за допомогою ресурсів впливати на політичний процес, як у внутрішньому (національному), так і в зовнішньому середовищі, що стало результатом змін і появи нових форм публічної взаємодії різних суб'єктів політики в процесі виробництва нових культурних і ідеологічних смислів, моделей комунікації і глобального управління [8, с. 160]. 
Важливим інструментом ефективної реалізації громадянами конституційного права на участь в управлінні державними справами $є$ їх залучення до прийняття рішень органами державної влади, зокрема - через механізм публічних консультацій. Публічні консультації - це процес комунікацій між органами державної влади, громадянами та зацікавленими сторонами, за допомогою якого сторони діалогу стають поінформованими про різні перспективи та пропозиції урядової політики і які надають можливість громадянам впливати на зміст рішень, що їх ухвалюють органи державної влади.

Консультації з громадськістю дозволяють посилити рівень довіри громадян до владних інститутів, налагодити ефективний діалог між владою та громадськістю, підвищити ступінь прозорості, прогнозованості, обгрунтованості та якості рішень, які ухвалюються органами державної влади та місцевого самоврядування, розширити доступ громадян до інформації про діяльність цих органів, забезпечити більш ефективне використання публічних фінансів, усунути ряд корупційних ризиків при прийнятті нормативно-правових актів [5, с. 15].

У більшості європейських країн спостерігається тенденція до розширення участі громадян у прийнятті рішень як на центральному, так і місцевому рівнях. При цьому дедалі частіше громадяни та інші зацікавлені суб'єкти залучаються до діалогу з владними структурами в онлайн режимі, що значно розширило можливості доступу громадян до процесу прийняття рішень, зробили його інтерактивним та прозорішим.

У Європейському Союзі е-консультації проводяться здебільшого Європейською Комісією, однак Європейський Парламент також має можливість за необхідності запускати на своїй платформі електронні консультації [7].

Однією з ефективних практик запровадження Платформи, зокрема для публічних консультацій, $\epsilon$ «ConsulProject» - безкоштовна платформа, з відкритим кодом, якою вже користуються 33 країни світу та 100 інституцій (адмініструється Мадридською міською радою). Вона постійно вдосконалюється в реальному часі завдяки поширенню досвіду користувачами платформи «Consul». Платформа пропонує безпечний інструмент для проведення е-консультацій, дебатів, подання пропозицій від громадськості голосування за проєкти Громадського бюджету та голосування за пропозиції громадян, в тому числі і за допомогою мобільного додатку [7].

Якщо ж говорити про досвід окремих країн у сфері розвитку е-консультацій, то останніми роками спостерігається тенденція до максимального залучення громадян до процесів формування та прийняття політичних рішень.

Орієнтація на діалог із суспільством, відкритість і прозорість, встановлення довіри до громадськості - невід'ємні складові публічного врядування. Оцінка даних індикаторів $є$ надійним інструментом покращення управління та вдосконалення діяльності міністерств, центральних органів виконавчої влади, адже ефективна взаємодія органів державної влади з громадськістю $є$ запорукою демократичного та відкритого суспільства. 3 даною метою уряди багатьох держав інтенсивно впроваджують інклюзивні платформи.

Так, Велика Британія має давню традицію проведення консультацій з громадянами та зацікавленими групами, у тому числі і е-консультації. Запуск UK Online24 у вересні 2000 року започаткував перше стандартизування онлайн-консультацій. 3 того часу уряд Великої Британії продовжує вдосконалювати способи консультацій шляхом встановлення більш пропорційного та цілеспрямованого підходу. Так, британським урядом було опубліковано оновлений набір принципів державних консультацій. Ці принципи дають чітке керівництво урядовим відомствам щодо порядку проведення е-консультацій. На сайті gov.uk зазначається: «Ми будемо використовувати переважно цифрові методи для консультацій 3 ширшою групою людей на більш ранньому етапі процесу формування політики. Тим самим полегшимо способи вираження громадськості своїх поглядів, і ми будемо намагатись використовувати чіткішу, простішу та зрозумілішу англійську мову в консультаційних документах. Ми також націлені на зменшенні ризику «втоми у консультаціях», консультуючись лише з тих питань, які справді того потребують» [2].

Платформа gov.uk, як єдина точка доступу, являє собою зручний у навігації та зрозумілий вебсайт. Всі е-консультації поділяються за 47 політичними сферами. Важливо, що на сайті в обов'язковому порядку регулярно публікуються звіти про результати проведення консультацій. Такі звіти включають в себе як статистичну інформацію, так і висновки, зроблені урядом, на основі е-консультацій. Така звітність є надзвичайно важливою, оскільки вона дозволяє учасникам не лише проаналізувати результати, але й зрозуміти наскільки впливовим був їх внесок, що суттєво мотивує їхню подальшу участь. Кожна веб-сторінка е-консультації містить також певні додаткові можливості, 
а саме: поділитися е-консультацією в соціальних мережах; перейти на веб-сторінки схожих за темою е-консультацій або ж оформити підписку на отримання новин.

Яскравим прикладом того наскільки клієнтоорієнтованим є підхід Великої Британії може бути проведена у 2020 році е-консультація «Спілкування з людьми із вадами слуху», що віднесена до політики «Рівність» та підпадає під категорію «call for evidence», тобто заклик до надання доказів про актуальну ситуацію.

Особливість цієї консультації полягала в тому, що урядом було спеціально відзнято серію відеороликів для того, щоб люди із вадами слуху могли повноцінно взяти участь в даній е-консультації. Відео-ролики розміщенні на сайті включали в себе одне відео, що пояснювало мету та цілі е-консультації, та ще два відео, що включали інформацію стосовно результатів е-консультації [2].

Не менш важливим фактором успішності е-консультацій у Великій Британії $\epsilon$ рівень проникнення сигналу Інтернет. Адже неможливо говорити про ефективність е-консультацій, якщо громадяни та інші зацікавлені сторони не мають необхідного рівня доступу до Інтернету.

Індекс телекомунікаційної інфраструктури у 2019 році вказував на недосконалість покриття сигналом Інтернет. Тим не менш, зважаючи на недосконалість покриття, та проблему вікового цифрового розриву, уряд не виключає відповідну категорію населення та дає їм можливість участі у консультаціях. Так, громадянин має три можливості для надання зворотного зв'язку, а саме: заповнити та надіслати відповідну форму через платформу розміщену на сайті gov.uk, надіслати електронного листа, або ж надіслати свої пропозиції поштою на адресу відповідного департаменту [1].

Успішний приклад запровадження механізму е-консультацій має й Королівство Нідерландів. Спільно із Великою Британією Нідерланди є одними зі світових лідерів із залучення громадян до державних процесів.

Інтернет-платформа для електронних консультацій в Нідерландах «Internet Consultatie.Nl» являє собою зручний в навігації веб-сайт. Більше того, дана платформа включає в себе можливості ознайомлення із вже існуючою законодавчою базою та пошук будь-якої необхідної інформації, яка, для зручності, поділяється на три категорії: фізичним особам, юридичним особам та урядова інформація. Така можливість існує завдяки об'єднанню двох платформ на одному сайті www.overheid.nl [1].

Загалом, на сторінці кожної окремої е-консультації розміщена вся необхідна для чіткого розуміння предмету консультації інформація, а саме: термін консультації; тип консультації; державний орган, що запустив консультацію; цільові групи; очікування від консультації та перелік документів, що складають предмет е-консультації. Окрім того, кожна веб-сторінка консультації містить додаткові можливості, як наприклад: роздрукувати е-консультацію; поділитися еконсультацією в соціальних мережах; оформити підписку на отримання новин на електронну поштову скриньку. Результати консультацій публікуються на тій же веб-сторінці, де розташована відповідна е-консультація.

Не зважаючи на те, що е-консультації в Нідерландах є достатньо розвинутими, Організація економічного співробітництва та розвитку виділяє такі проблеми [1]:

- слабка координація між органами на державному рівні щодо проведення консультацій, що призводить до «втоми від консультацій» у громадян;

- недостатність зусиль спрямованих на координацію дій уряду для проведення консультацій (хоча участь зацікавлених сторін у прийнятті рішень є обов'язковою вимогою, немає ніяких доказів того, що така участь урядом використовується);

- слабке інтернет покриття у деяких регіонах країни;

- відсутність уніфікації термінології для опису зацікавлених сторін-учасників консультацій [1].

Підсумовуючи досвід впровадження е-консультацій у Великій Британії та Нідерландах, варто зазначити, що загальна оцінка практики з проведення е-консультацій є дієвою. Важливим $є$ також бажання уряду відповідати потребам громадськості, яке проявляється через проведення спеціальних е-консультацій для оцінки існуючої системи. Більше того, публічний характер онлайн консультацій сприяє прозорості процесу прийняття політичних рішень. Тим не менш, варто враховувати, що досліджені країни все ще мають певну кількість прогалин у процесі реалізації публічних еконсультацій, які здебільшого мають технічний характер.

Окрім того, у деяких європейських країнах в органах виконавчої влади функціонують структури відповідальні за залучення громадськості у процесі формування та реалізації політики, у тому числі у онлайн режимі. 
Так, наприклад, у Хорватії експертний підрозділ уряду, який відповідає за розвиток та сприяння взаємодії уряду з організаціями громадянського суспільства (далі ОГС) - Державний офіс з питань співпраці із НУО. Офіс здійснює координацію роботи міністерств, центральних державних офісів, урядових офісів та державних адміністративних органів, а також адміністративних органів на місцевому рівні щодо моніторингу та покращення їхньої взаємодії із сектором ОГС [4].

У 2009 році даний орган розробив Керівні принципи щодо впровадження «Кодексу практик 3 проведення консультацій з зацікавленими сторонами щодо процедур прийняття законів та інших регуляторних та законодавчих актів». Також Офіс розробив інструменти для публічних службовців (інструкції та форми для здійснення публічних консультацій) та надавав службовцям методичні рекомендації й підтримку у цій сфері. 3 моменту прийняття Кодексу основними ключовими завданнями Державного офісу з питань співпраці з НУО були [3]:

- розробка систематичних тренінгових програм для призначених координаторів із проведення консультацій в органах влади та офісах;

- регулярний моніторинг впровадження Кодексу та підготовка річних звітів (передбачає детальні річні звіти стосовно процесу впровадження);

- розробка та вдосконалення державного веб порталу публічних консультацій «e-Savjetovanja».

До 2019 року Офіс вважався головним органом влади, відповідальним за впровадження стандартів громадської участі у процес прийняття рішень. У 2019 році ця сфера компетенції перейшла до Державного офісу з питань законодавства.

Важливу роль у даній системі відіграє Інформаційний Комісар (IК), який відповідає за впровадження Закону «Про право на доступ до публічної інформації», у якому серед іншого, визначено обов'язок органів виконавчої влади проводити консультації із громадськістю під час розробки законів та нормативних актів. Будь-який громадянин може звернутися зі скаргою до Інформаційного Комісара у тому разі, якщо не було проведено публічну консультацію, або проведення консультації не відбулося відповідно до встановлених процедур [7, с.88].

Окрім того, в Уряді Республіки Хорватія існує мережа координаторів з проведення консультацій - це окремі службовці у міністерствах та державних офісах, які пройшли тренінги 3 питань впровадження стандартів у проведенні публічних консультацій. Координатори з проведення консультацій повинні володіти ключовою інформацією про усі поточні пропозиції стосовно законодавства у їхньому департаменті/офісі, а також стосовно процесу здійснення консультацій щодо цих пропозицій. Так, громадськість та компетентний орган, що займається розробкою проєкту закону або інших нормативних актів, мають змогу звернутися до координатора у будь-який час з метою розв'язання певних питань або отримання допомоги щодо публічних консультацій $[7$, с.88].

У Сербії відповідальність за надання підтримки та формування громадського діалогу між державними установами та ОГС покладено на Офіс з питань співпраці з громадянським суспільством, підрозділу Уряду Сербії, який був створений у 2010 році [1].

Даний Офіс спільно з Офісом з питань європейської інтеграції створили спеціальний майданчикплатформу «Механізм секторальної підтримки організацій громадянського суспільства (SEKO)» 3 метою покращення та налагодження конструктивного діалогу між державою та громадянським суспільством.

SEKO - це механізм для проведення консультацій, що розподілений на сектори, зокрема сектор верховенства права, реформ державного управління, економічного, енергетичного, сільськогосподарського розвитку та розвитку сільської місцевості тощо. Запропонована платформа сприяє [1]:

- комунікації та взаємодії між міністерствами та різноманітними державними офісами та ОГС;

- формуванню мережі організацій, залучених до його використання;

- встановленню та впровадженню механізмів для здійснення комунікації та обміну інформацією між мережею організацій, залучених до його використання;

- участі у консультаціях у процесі прийняття рішень та моніторингу програм його порядку денного.

Механізм SEKO допомагає у розв'язанні таких проблем: короткі терміни проведення консультацій; недостатня поінформованість міністерств про важливість залучення ОГС у питаннях використання міжнародних фондів; відсутність зацікавленості та/або людських та фінансових ресурсів у ОГС для участі у процесі прийняття рішень; сприяння залученню ОГС тощо. У 2016 році Офіс з питань європейської інтеграції підписав Меморандум із дев’ятьма ОГС, які займають перші позиції із використання механізму SEKO, що офіційно закріпило їхню поточну співпрацю та спільні дії [1]. 
На сьогоднішній день в Україні участь громадськості у формуванні та реалізації політики врегульована частково. Основне право кожного громадянина на участь у процесах державотворення закріплено в Конституції України. Значною мірою проведення електронних консультацій і публічних громадських обговорень регулюється Постановою Кабінету Міністрів України від 3 листопада 2010 року № 996 «Про забезпечення участі громадськості у формуванні та реалізації державної політики». Але ця Постанова має рекомендаційний характер для органів місцевого самоврядування, i iii не можна застосовувати в діяльності інших, крім органів виконавчої влади, суб'єктів державновладних повноважень [6].

Е-консультації є інструментом електронної демократії, розвиток якого, згідно з розпорядженням Кабінету Міністрів України «Про схвалення Стратегії розвитку інформаційного суспільства» від 15 травня 2013 року № 386, визначено одним із пріоритетних напрямів державної політики. У Концепції розвитку електронної демократії України електронні консультації визначені як «форма публічних консультацій, що передбачає, зокрема, оприлюднення проектів актів органів державної влади або питань, що потребують вирішення, для отримання пропозицій та зауважень». Але на законодавчому рівні в Україні поняття «електронні консультації» передбачає саме вертикальний вектор взаємодії між органами влади та громадянами [5, с.63].

Для органів місцевого самоврядування, як уже було зазначено, консультації з громадськістю практично жодним чином не врегульовані на рівні законодавства. При цьому місцеві ради можуть самостійно визначати порядок і конкретні формати проведення консультацій шляхом їх закріплення у статуті та інших нормативно-правових актах. Привітні до громади міста активно використовують механізм публічних консультацій, залучаючи зацікавлену громадськість до процесу прийняття рішень на різних етапах і в різноманітних формах. Те саме можна сказати про міністерства, які зараз реформуються, хоча більшість міст і міністерств України все ще залишаються закритими клубами 3 наявними окремими елементи консультацій у формі дорадчо-консультативних органів з фіксованим складом учасників [5, с. 63].

Відповідно до Плану заходів «Відкритий парламент» за підтримки Програми USAID PAДА та за ініціативи Управління комп'ютеризованих систем Апарату Верховної Ради України було розроблено «Портал громадського обговорення законопроектів»- один із ресурсів веб-порталу Верховної Ради України, мета якого - залучити громадян до законодавчого процесу через ознайомлення, коментування та висловлення зауважень i пропозицій до законопроектів, запропонованих для обговорення в онлайн-режимі [4, с. 22].

Портал у тестовому режимі з'явився ще наприкінці 2016 р., за 5 років існування його інтерфейс був суттєво доопрацьований. Власне, поява окремої платформи для громадського обговорення законопроектів уже $\epsilon$ позитивним зрушенням, яке відповідає загальносвітовим тенденціям. Окрім того, на порталі ВРУ інтегровані й інші інструменти е-участі, зокрема е-петиції та е-звернення. Однак суттєвим недоліком залишається низька поінформованість/ низький рівень зацікавленості громадян цим ресурсом, як результат - низькі показники голосування. Також не всі розуміють тексти, написані юридичною мовою, і тим більше їхню суть, що теж знижує зацікавленість потенційних учасників обговорення відповідних НПА [5, с. 63].

По-друге, громадськість залучається до консультацій уже на стадії створеного законопроекту, що негативно впливає на можливість внесення суттєвих змін. По-третє, на сайті відсутня інформація про результати консультації, є лише статистична інформація. I нарешті, лишається можливість для окремих законопроектів, розміщених на порталі для консультацій- не проходити процедуру. Із історії завершених публічних консультацій можна констатувати, що найбільшу зацікавленість у громадськості викликав Проект Закону «Про цивільну зброю і боєприпаси»: 854 голоси «за» i 7 - «проти» [5, с. 65].

Згідно з аналітичними даними Єдиного веб-порталу органів виконавчої влади України за 2020 p., е-консультації $є$ найпоширенішим методом консультування міністерств, інших центральних органів виконавчої влади та місцевих органів виконавчої влади. Більше $50 \%$ питань, винесених на консультації з громадськістю, становлять проєкти нормативно-правових актів. Найактивніше виносять питання на публічні консультації Міністерство освіти та науки України, Фонд Державного майна України та Київська міська державна адміністрація.

Однією з характерних рис використання електронних консультацій в Україні на місцевому рівні $€$ розпорошеність відповідних сервісів на різних електронних платформах - здебільшого це веб-сайти установ, що ініціюють проблемне питання/документ для публічного обговорення. У межах швейцарсько-української програми EGAP розроблена «Єдина платформа місцевої електронної 
демократії», куди увійшли уже сервіси «Місцеві електронні петиції», «Громадський бюджет», «Відкрите місто», а також «Електронні консультації з громадськістю». Саме останній інструмент дає органам місцевого самоврядування можливість залучати пропозиції мешканців з питань розвитку міст і громад, організовувати обговорення проектів документів перед їх розглядом та схваленням, проводити місцеве опитування в різних формах задля вивчення думки 30 активної частини жителів. Зараз також активно просувають низку сайтів для простого голосування, але авторизація через ці сервіси не дає змоги гарантувати унікальність голосу [7, с.15].

Оскільки електронні консультації $є$ порівняно новою практикою е-участі в Україні, наразі важливо поширити просвітницьку й інформаційну кампанію стосовно ефективних механізмів реалізації цього інструменту. Інакше є ризик суто формального впровадження, коли е-консультації де-юре впроваджені, але де-факто малоефективні. Тут визначальну роль має професійність модераторів цього бізнес-процесу на всіх етапах з боку відповідних органів влади. Якщо громадськість, активні мешканці, соціально відповідальний бізнес переконаються, що «їх чують», то рівень залучення і якість зворотного зв'язку від громадськості помітно зростатиме.

Здійснене дослідження європейської практики впровадження публічних електронних консультацій в окремих європейських країнах дозволяє зробити наступні висновки. Для проведення ефективних електронних консультацій однаково важливими є як технічний бік забезпечення процесу (створення спеціальних платформ для проведення е-консультацій, розробка зрозумілого та доступного інтерфейсу таких платформ, використання зрозумілої мови), так і загальний підхід до організації е-консультацій (залучення зацікавлених сторін на ранніх стадіях прийняття рішення, вибір сфер залучення, популяризація е-консультацій, відкритість аналізу результатів). Важливим у формуванні успішної практики проведення електронних консультацій $\epsilon$ також системність та комплексність підходу. Так, окрім впровадження онлайн-ресурсів для проведення е-консультацій громадян має проводитись паралельна офлайн робота з громадськими групами, представниками громадськості при державних органах, у вигляді конференцій, рад, круглих столів та ін. Саме такий повний цикл співпраці, може забезпечити результативність громадської участі.

Таким чином, практика електронних консультацій, що проводяться на теренах Європейського Союзу, відрізняється від українського своїм структурним та систематичним підходом. Громадяни залучаються на всіх стадіях прийняття рішення, мають рівний та зрозумілий доступ до е-консультацій. Органами ЄС проводяться широкі роз'яснювальні програми для більшого залучення громадян. Аналіз результатів електронних консультацій відбувається систематично та регулярно публікується на офіційному сайті. Уряди європейських країн забезпечують високий рівень організації процесу, вони є доступними та враховують потреби громадян, а результати е-консультацій мають реальний вплив на прийняття кінцевого рішення.

\section{Бібліографічний список:}

1. E-public, e-participation and e-voting in Europe - prospects and challenges. Science and 9 Technology Options Assessment, final report. European Parliament, 2019.

2. GOV.UK URL: https://www.gov.uk/

3. Tomkova J. E-consultations - new tools for civic engagement or facades for political correctness? European Journal of ePractice, 7, March 2019.

4. Кодекс кращих практик участі громадськості у процесі прийняття рішень CONF/PLE(2009)CODE1. Конференція міжнародних неурядових організацій Ради Європи, 1.10.2017.

5. Механізми владно-громадської взаємодії в ОТГ: успішні практики. ВГО «Асоціація сприяння самоорганізації населення», квітень 2019.

6. Посібник з інформації, консультацій та громадської участі у формуванні та проведенні політичного курсу. OECD, 2001.

7. Світлична А., Смельянова А., Лобойко С. Електронні консультації Європейська практика: аналітична записка. Центр розвитку інновацій, 2018. URL: http://cid.center/index.php/7076363.

8. Чальцева О. М. Публічна політика: теоретичний вимір і сучасна практика: монографія. Вінниця: ФОП Барановська Т. П., 2018. 336 с.

\section{References:}

1. E-public, e-participation and e-voting in Europe - prospects and challenges. Science and 9 Technology Options Assessment, final report. European Parliament, 2019.

2. GOV.UK URL: https://www.gov.uk/

3. Tomkova J. E-consultations - new tools for civic engagement or facades for political correctness? European Journal of ePractice, 7, March 2019. 
4. Kodeks krashchykh praktyk uchasti hromads'kosti u protsesi pryynyattya rishen' CONF/PLE(2009)CODE1. Konferentsiya mizhnarodnykh neuryadovykh orhanizatsiy Rady Yevropy, 1.10.2017.

5. Mekhanizmy vladno-hromads'koyi vzayemodiyi v OTH: uspishni praktyky. VHO «Asotsiatsiya spryyannya samoorhanizatsiyi naselennya», kviten' 2019.

6. Posibnyk $\mathrm{z}$ informatsiyi, konsul'tatsiy ta hromads'koyi uchasti u formuvanni ta provedenni politychnoho kursu. OECD, 2001.

7. Svitlychna A., Yemel'yanova A., Loboyko S. Elektronni konsul'tatsiyi Yevropeys'ka praktyka: analitychna zapyska. Tsentr rozvytku innovatsiy, 2018. URL: http://cid.center/index.php/7076363.

8. Chal'tseva O. M. Publichna polityka: teoretychnyy vymir i suchasna praktyka: monohrafiya. Vinnytsya: FOP Baranovs'ka T. P., 2017. 336 s.

\section{Chaltseva O. M., Shvets K. A. Experience of Implementation of Public E-consultations in European Countries}

The article examines the experience of implementing public e-consultations in European countries, including the United Kingdom, the Netherlands, Croatia, Serbia and Ukraine.

It was found that public consultations, including in electronic format, strengthen citizens' trust in government institutions, establish an effective dialogue between government and the public, increase transparency, predictability, reasonableness and quality of decisions made by public authorities and local governments, expand access. citizens to information about the activities of these bodies, to ensure more efficient use of public finances, to eliminate a number of corruption risks in the adoption of regulations.

Due to the introduction of public online consultations in public policy in the studied European countries, it has been established that public consultation has a structural and systematic approach, and the public nature of online consultations contributes to the transparency of the political decision-making process; modernization of the process of public administration is provided in accordance with the new conditions of institutional development; increases the efficiency and effectiveness of government and state institutions, as well as the possibility of sustainable feedback between government, business and citizens.

It was found that Ukraine is actively involved in the interactive process, which can be attributed to the positive effects of institutionalization of public policy. However, it should be noted that in Ukraine, public consultations with the public are in almost no way regulated by law. At the same time, local councils independently determine the procedure and specific formats of consultations by enshrining them in the statute and other regulations. The introduction of electronic technologies in the field of public administration and the expansion of information space allows public authorities not only to provide better services, but also to decentralize, while strengthening the horizontal links between government, strengthening feedback between government and citizens. Public consultations in the modern political space of Ukraine are aimed at ensuring constant adjustment of the activities of the authorities taking into account the wishes and requests of the population.

Keywords: public policy, public administration, public consultation, public authorities, civil society, public e-consultations. 